\title{
Growth and Yield of Soybean under Varied Environments and Plant Densities in South Telangana Agro Climatic Zone
}

\author{
N. Mahesh ${ }^{1}$, G. Sreenivas ${ }^{2}$, P. Leela Rani ${ }^{3 *}$, Akhilesh Gupta ${ }^{4}$, \\ P.D. Sreekanth ${ }^{5}$ and K. Surekha ${ }^{6}$ \\ ${ }^{1}$ Department of Agronomy, College of Agriculture, ${ }^{2}$ Agro Climate Research Center, ARI, \\ ${ }^{3}$ AICRP on Weed Management, College of Agriculture, Professor Jayashankar Telangana State \\ Agricultural University, Rajendranagar, Hyderabad - 500 030, \\ ${ }^{4}$ Department of Science and Technology, New Delhi \\ ${ }^{5}$ NAARM, Rajendranagar, Hyderabad, ${ }^{6}$ IIRR, Rajendranagar, Hyderabad \\ *Corresponding author
}

\begin{tabular}{|c|c|}
\hline & A B S T R A C T \\
\hline & \multirow{6}{*}{ 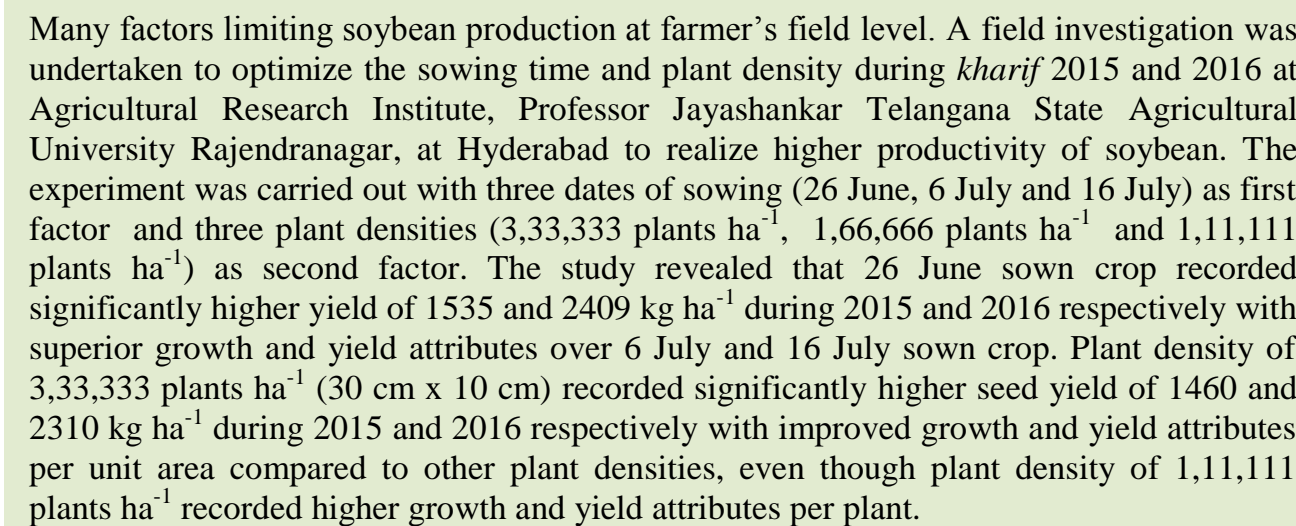 } \\
\hline & \\
\hline & \\
\hline $\begin{array}{l}\text { Sowing dates, } \\
\text { Seed yield. }\end{array}$ & \\
\hline Article Info & \\
\hline $\begin{array}{l}\text { Accepted: } \\
\text { 19 June } 2017 \\
\text { Available Online: } \\
\text { 10 August } 2017\end{array}$ & \\
\hline
\end{tabular}

\section{Introduction}

Soybean (Glycine max. L. Merrill) has a prominent position among the legumes that supplement nearly one-third of the world population and popularly known as "Miracle Bean" because of its versatility. Soybean has been considered as one of the potential rainy season crop in the rainfed regions of central and southern India and grown over an area of 10.9 million hectares with a production of 11.46 million tonnes and productivity of 951 $\mathrm{kg} \mathrm{ha}^{-1}$. The area under soybean in India has increased from 0.03 to 10.9 million ha during the period from 1970 to 2016 (SOPA, 2016). There are many factors limiting soybean production at farmer's farm.

Among these factors improper sowing time, climatic variability, low germination percentage, poor quality seed and moisture stress. Among these factors sowing time and plant densities are the important factors affecting soybean growth and development, grain yield (Zhang et al., 2010) and seed quality (Rahman et al., 2005). 
Sowing dates influence soybean growth stages, due to variation in photoperiod (Han et al., 2006; Kumudini et al., 2007), air temperature (Chen \& Wiatrak, 2010), and rainfall distribution and amount during the crop cycle (Hu \& Wiatrak, 2012). The time of sowing has a considerable influence on growth and yield of soybean. Early sowing in the season may have poor emergence or limited growth. When the crop is exposed to hot temperatures, days shorter than critical length, they progress rapidly towards maturity. If this occurs before the plant reaches an adequate size, the soybean crop is stunted and gives low yield (Boquet and Clawson, 2007). However, delayed sowing may shrink the vegetative phase, which in turn reduces the dry matter accumulation leading to poor partitioning to reproductive parts and ultimately poor realization of the potential yield (Hari Ram et al., 2011).

Planting density is an important determinant of seed yield and it plays a pivotal role in modulating the environmental factors related to growth and development of the crop. The optimum plant density with proper geometry of planting is dependent on variety, its growth habit and agro-climatic conditions. Plant density is considered to be one of the main factors of production which greatly influences light absorption into the plant cover (Board, 2002).

Keeping the above points in view the present study was conducted to evaluate the effect of sowing dates and plant densities on growth and yield of soybean.

\section{Materials and Methods}

The field experiment was conducted at Agricultural Research Institute, Rajendranagar, Hyderabad having $17^{0} 19^{\prime} \mathrm{N}$ Latitude, $78^{0} 23^{\prime}$ E Longitude and $542.3 \mathrm{~m}$ above mean sea level. The experiment was laid out in randomized block design (factorial) with three sowing dates (26 June, 6 July and 16 July) as one factor and three plant densities $\left(3,33,333\right.$ plants $\mathrm{ha}^{-1}(30 \mathrm{~cm} \times 10$ $\mathrm{cm}), \quad 1,66,666$ plants $\mathrm{ha}^{-1}(30 \mathrm{~cm} \times 20 \mathrm{~cm})$ and $1,11,111$ plants $\mathrm{ha}^{-1}(30 \mathrm{~cm} \times 10 \mathrm{~cm})$ as another factor, replicated thrice. The soil of the experimental site was sandy loam in texture, neutral in reaction, low in available nitrogen, phosphorus and high in available potassium. The other package of practices used recommended for raising the crop. Data on different characters viz., growth and yield components and yield, were subjected to analysis of variance procedures as outlined for randomized block design, factorial concept (Gomez and Gomez, 1984). Statistical significance was tested by $\mathrm{F}$-value at 0.05 level of probability and critical difference was worked out where ever the effects were significant.

\section{Results and Discussion}

\section{Plant height (cm)}

Based on the analysis of variance (Table 1), sowing date and plant densities had a significant effect on all growth attributes. During both the years of study plant height increased as the age of crop advanced. Maximum plant height was recorded in 26 June sown crop and significantly superior to 6 July and 16 July sown crop, during 2015 and 2016 at all the growth stages except end of the juvenile phase where 6 July and 16 July were onpar with each other during 2015, 26 June and 6 July were on par each other during 2016. This decrease in the plant height under delayed sowing might be due to shorter vegetative period and low canopy competition among the plants. These results were in line with Wade and Johnston (1975) who stated that photoperiod sensitivity had marked reduction in growth period due to delayed sowing. It appears that early planting results 
better use of water and nutrients and there by plant height could be more (Yari et al., 2013). Plant density of $3,33,333(30 \mathrm{~cm} \times 10 \mathrm{~cm})$ plants ha ${ }^{-1}$ showed more plant height and was on par with $1,66,666$ plants ha ${ }^{-1}(30 \mathrm{~cm} \mathrm{x} 20$ $\mathrm{cm})$. The lowest plant height was recorded in 1, 11,111 plants ha ${ }^{-1}$ inturn, 1, 66,666 plants $\mathrm{ha}^{-1}$ and $1,11,111$ plants ha ${ }^{-1}$ were comparable with each other. The increased plant height might be due to morphological changes in plant due to increased density mainly because of competition for light when soil fertility and moisture are not limited. Increased plant density results in mutual shading of plants which usually results in stem elongation. However the number of nodes on the main stem decreased, suggesting internode elongation was responsible for the height increase (Rahman et al., 2004).

\section{Leaf Area Index (LAI)}

The LAI decreased with delay in sowing from 26 June to 16 July during both the years. Maximum LAI was observed in 26 June sown crop and was significantly superior to 6 July and 16 July sown crop. Crop sown on 16 July showed the lowest LAI at all growth stages.

Among plant densities significantly higher LAI was noticed with 3,33,333 plants ha ${ }^{-1}$ and was significantly superior to $1,66,666$ plants $\mathrm{ha}^{-1}$ and $1,11,111$ plants $\mathrm{ha}^{-1}$ at the end of juvenile phase, flowering, pod development and physiological maturity stages during 2015 and 2016 (Table 2). Higher values of LAI with higher plant densities might be ascribed to the more plant stand coupled with taller plants having more leaves resulted in more LAI (Bilal et al., 2009).

\section{Yield attributes}

Analysis of data revealed that all the yield and yield attributes were significantly $(\mathrm{p} \leq 0.05)$ affected due to variable weather conditions and plant densities (Table 3). Maximum number of pods plant ${ }^{-1}$ and seeds pod ${ }^{-1}$, seeds $\mathrm{m}^{-2}$ and 100 seed weight was noticed in crop which sown on 26 June and was significantly superior to 6 July and 16 July sown crop. Late planting reduces number of pod plant ${ }^{-1}$ due to decreasing growing period due to decrease vegetative growth (Yari et al., 2013). The decrease in number of seeds pod might be due to the less rate of translocation of assimilates to soybean pods during pod development phase because of prevailing lower range of maximum temperature under late sown crop (Kumar et al., 2008).

Among plant densities more number of pods plant $^{-1}$, seeds pod $^{-1}$ and 100 seed weight was obtained at reduced plant density of $1,11,111$ plants $\mathrm{ha}^{-1}$. Whereas more number of seeds $\mathrm{m}^{-}$ 2 was observed in 3, 33,333 plants $\mathrm{ha}^{-1}$. Though, lower plant density might result in higher mean number of branches, pods and seeds plant ${ }^{-1}$ and 100-seed weight due to low inter plant competition, but the number of seeds $\mathrm{m}^{-2}$ was lower due to inadequate plant population per unit area (Hari Ram et al., 2011).

\section{Seed and haulm yield $\left(\mathrm{kg} \mathrm{ha}^{-1}\right)$}

The effect of sowing time and plant density on seed and haulm yield was significant (Table 4). The highest seed and haulm yield was obtained with 26 June sown crop and was significantly superior to 6 July and 16 July sown crop. Such increase in seed yield may be attributed in to the considerable increase in number of pods per plant and 1000-seed weight. The variation in the total amount of rainfall received during the crop period might be the reason for yield variation in 2015 and 2016. Early sowing provides long vegetative and reproductive growth periods there by, facilitating the crop to produce more biomass, which enhanced the number of pods plant ${ }^{-1}$, seeds pod $^{-1}$ and 100-seed weight (Kumar et al., 2005). 
Table.1 Plant height $(\mathrm{cm})$ of soybean at different growth stages under different dates of sowing and plant densities

\begin{tabular}{|c|c|c|c|c|c|c|c|c|}
\hline \multirow[b]{3}{*}{ Date of sowing (D) } & \multicolumn{8}{|c|}{ Crop Growth Stages } \\
\hline & \multicolumn{2}{|c|}{ End of juvenile stage } & \multicolumn{2}{|c|}{$\begin{array}{c}\text { Flowering } \\
\text { stage }\end{array}$} & \multicolumn{2}{|c|}{$\begin{array}{c}\text { Pod development } \\
\text { stage }\end{array}$} & \multicolumn{2}{|c|}{$\begin{array}{l}\text { Physiological } \\
\text { maturity stage }\end{array}$} \\
\hline & 2015 & 2016 & 2015 & 2016 & 2015 & 2016 & 2015 & 2016 \\
\hline 26 June & 10.6 & 12.5 & 35.5 & 39.0 & 42.1 & 59.3 & 46.2 & 62.8 \\
\hline 06 July & 9.8 & 12.4 & 27.2 & 28.1 & 34.4 & 47.5 & 37.0 & 54.5 \\
\hline 16 July & 9.8 & 11.7 & 22.8 & 23.0 & 30.7 & 40.6 & 31.9 & 45.5 \\
\hline S.Em \pm & 0.2 & 0.2 & 0.9 & 1.0 & 0.9 & 1.1 & 1.3 & 0.8 \\
\hline $\mathrm{CD}(\mathrm{P}=0.05)$ & 0.6 & 0.6 & 2.8 & 3.0 & 2.7 & 3.3 & 3.8 & 2.3 \\
\hline \multicolumn{9}{|l|}{ Plant densities (S) } \\
\hline $30 \times 10 \mathrm{~cm}\left(3,33,333\right.$ plants ha $\left.^{-1}\right)$ & 10.2 & 12.7 & 30.6 & 32.2 & 37.9 & 51.9 & 42.4 & 56.4 \\
\hline $30 \times 20 \mathrm{~cm}\left(1,66,666\right.$ plants ha $\left.{ }^{-1}\right)$ & 10.1 & 12.0 & 27.9 & 30.0 & 35.5 & 49.2 & 38.6 & 54.1 \\
\hline $30 \times 30 \mathrm{~cm}\left(1,11,111\right.$ plants ha $\left.^{-1}\right)$ & 10.0 & 11.9 & 25.9 & 27.9 & 33.8 & 46.2 & 34.9 & 52.2 \\
\hline S.Em \pm & 0.2 & 0.2 & 0.9 & 1.0 & 0.9 & 1.1 & 1.3 & 0.8 \\
\hline $\mathrm{CD}(\mathrm{P}=0.05)$ & NS & 0.6 & 2.8 & 3.0 & 2.7 & 3.3 & 3.8 & 2.3 \\
\hline \multicolumn{9}{|l|}{ Interaction (D X S) } \\
\hline S. Em \pm & 0.3 & 0.33 & 1.6 & 1.7 & 1.6 & 1.9 & 2.2 & 1.3 \\
\hline $\mathrm{CD}(\mathrm{P}=0.05)$ & NS & NS & NS & NS & NS & NS & NS & NS \\
\hline
\end{tabular}

Table. 2 Leaf area index (LAI) of soybean at different growth stages under different dates of sowing and plant densities

\begin{tabular}{|c|c|c|c|c|c|c|c|c|}
\hline \multirow[b]{3}{*}{ Date of sowing (D) } & \multicolumn{8}{|c|}{ Crop Growth Stages } \\
\hline & \multicolumn{2}{|c|}{$\begin{array}{c}\text { End of } \\
\text { juvenile stage }\end{array}$} & \multicolumn{2}{|c|}{$\begin{array}{c}\text { Flowering } \\
\text { stage }\end{array}$} & \multicolumn{2}{|c|}{$\begin{array}{c}\text { Pod development } \\
\text { stage }\end{array}$} & \multicolumn{2}{|c|}{$\begin{array}{c}\text { Physiological } \\
\text { maturity stage }\end{array}$} \\
\hline & 2015 & 2016 & 2015 & 2016 & 2015 & 2016 & 2015 & 2016 \\
\hline 26 June & 0.31 & 0.34 & 3.68 & 3.74 & 5.10 & 5.13 & 1.55 & 1.87 \\
\hline 06 July & 0.22 & 0.24 & 2.56 & 3.12 & 4.19 & 4.48 & 1.09 & 1.57 \\
\hline 16 July & 0.17 & 0.17 & 2.01 & 2.01 & 2.55 & 3.09 & 0.51 & 1.22 \\
\hline S.Em \pm & 0.01 & 0.01 & 0.09 & 0.1 & 0.28 & 0.13 & 0.14 & 0.10 \\
\hline $\mathrm{CD}(\mathrm{P}=0.05)$ & 0.04 & 0.03 & 0.26 & 0.3 & 0.82 & 0.4 & 0.41 & 0.30 \\
\hline \multicolumn{9}{|l|}{ Plant densities (S) } \\
\hline $30 \times 10 \mathrm{~cm}\left(3,33,333\right.$ plants $\left.^{-1}\right)$ & 0.29 & 0.34 & 3.60 & 3.84 & 5.23 & 5.68 & 1.52 & 2.06 \\
\hline $30 \times 20 \mathrm{~cm}\left(1,66,666\right.$ plants $\left.^{-1}\right)$ & 0.24 & 0.24 & 2.69 & 2.93 & 3.90 & 3.91 & 1.05 & 1.64 \\
\hline $30 \times 30 \mathrm{~cm}\left(1,11,111\right.$ plants ha $\left.^{-1}\right)$ & 0.17 & 0.17 & 1.96 & 2.10 & 2.70 & 3.11 & 0.58 & 0.96 \\
\hline S.Em \pm & 0.01 & 0.01 & 0.09 & 0.1 & 0.28 & 0.13 & 0.14 & 0.10 \\
\hline $\mathrm{CD}(\mathrm{P}=0.05)$ & 0.04 & 0.03 & 0.26 & 0.3 & 0.82 & 0.4 & 0.41 & 0.30 \\
\hline \multicolumn{9}{|l|}{ Interaction (D X S) } \\
\hline S. Em \pm & 0.02 & 0.02 & 0.15 & 0.18 & 0.48 & 0.23 & 0.24 & 0.18 \\
\hline $\mathrm{CD}(\mathrm{P}=0.05)$ & NS & NS & NS & NS & NS & NS & NS & NS \\
\hline
\end{tabular}


Table.3 Yield attributes of soybean as influenced by dates of sowing and plant densities

\begin{tabular}{|c|c|c|c|c|c|c|c|c|}
\hline \multirow[b]{3}{*}{ Date of sowing (D) } & \multicolumn{8}{|c|}{$\begin{array}{l}\text { Yield } \text { attributes } \\
\end{array}$} \\
\hline & \multicolumn{2}{|c|}{$\begin{array}{c}\text { Number of pods } \\
\text { plant }^{-1}\end{array}$} & \multicolumn{2}{|c|}{$\begin{array}{c}\text { Number seeds } \\
\text { pod }^{-1}\end{array}$} & \multicolumn{2}{|c|}{$\begin{array}{c}\text { Number of } \\
{\text { seeds } \mathbf{m}^{-2}}^{\text {nat }} \\
\end{array}$} & \multicolumn{2}{|c|}{ Seed index $(g)$} \\
\hline & 2015 & 2016 & 2015 & 2016 & 2015 & 2016 & 2015 & 2016 \\
\hline 26 June & 79 & 101 & 2.8 & 2.8 & 3805 & 5026 & 11.2 & 14.2 \\
\hline 06 July & 68 & 90 & 2.7 & 2.7 & 3151 & 4353 & 9.7 & 13.6 \\
\hline 16 July & 56 & 79 & 2.6 & 2.6 & 2475 & 3687 & 8.6 & 13.0 \\
\hline S.Em \pm & 3 & 3 & 0.04 & 0.03 & 161 & 147 & 0.10 & 0.10 \\
\hline $\mathrm{CD}(\mathrm{P}=0.05)$ & 7 & 8 & 0.12 & 0.08 & 474 & 436 & 0.29 & 0.28 \\
\hline \multicolumn{9}{|l|}{ Plant densities (S) } \\
\hline $30 \times 10 \mathrm{~cm}\left(3,33,333\right.$ plants ha $\left.^{-1}\right)$ & 45 & 64 & 2.6 & 2.6 & 3847 & 5530 & 9.6 & 13.3 \\
\hline $30 \times 20 \mathrm{~cm}\left(1,66,666\right.$ plants $\left.^{-1}\right)$ & 70 & 91 & 2.7 & 2.7 & 3119 & 4049 & 9.9 & 13.6 \\
\hline $30 \times 30 \mathrm{~cm}\left(1,11,111\right.$ plants $\left.^{-1}\right)$ & 88 & 116 & 2.8 & 2.8 & 2464 & 3487 & 10.1 & 14.0 \\
\hline S.Em \pm & 3 & 3 & 0.04 & 0.03 & 161 & 147 & 0.10 & 0.10 \\
\hline $\mathrm{CD}(\overline{\mathrm{P}}=0.05)$ & 7 & 8 & 0.12 & 0.08 & 474 & 436 & 0.29 & 0.28 \\
\hline \multicolumn{9}{|l|}{ Interaction (D X S) } \\
\hline S. Em+ & 4 & 5 & 0.07 & 0.05 & 279 & 257 & 0.17 & 0.17 \\
\hline $\mathrm{CD}(\mathrm{P}=0.05)$ & NS & NS & NS & NS & NS & NS & NS & NS \\
\hline
\end{tabular}

Table.4 Seed yield and haulm yield $\left(\mathrm{kg} \mathrm{ha}^{-1}\right)$ of soybean under different dates of sowing and plant densities

\begin{tabular}{|c|c|c|c|c|}
\hline Treatments & \multicolumn{2}{|c|}{ Seed yield $\left(\mathrm{kg} \mathrm{ha}^{-1}\right)$} & \multicolumn{2}{|c|}{ Haulm yield $\left(\mathrm{kg} \mathrm{ha}^{-1}\right)$} \\
\hline Date of sowing (D) & 2015 & 2016 & 2015 & 2016 \\
\hline 26 June & 1523 & 2409 & 1939 & 3182 \\
\hline 06 July & 1277 & 2002 & 1650 & 2290 \\
\hline 16 July & 1027 & 1704 & 1338 & 1747 \\
\hline S.Em \pm & 34 & 41 & 49 & 55 \\
\hline $\mathrm{CD}(\overline{\mathrm{P}}=0.05)$ & 100 & 121 & 144 & 161 \\
\hline \multicolumn{5}{|l|}{ Plant densities (S) } \\
\hline $30 \times 10 \mathrm{~cm}\left(3,33,333\right.$ plants ha $\left.^{-1}\right)$ & 1460 & 2310 & 1924 & 2818 \\
\hline $30 \times 20 \mathrm{~cm}\left(1,66,666\right.$ plants ha $\left.^{-1}\right)$ & 1277 & 2031 & 1631 & 2453 \\
\hline $30 \times 30 \mathrm{~cm}\left(1,11,111\right.$ plants $\left.^{-1}\right)$ & 1089 & 1774 & 1372 & 1948 \\
\hline S.Em \pm & 34 & 41 & 49 & 55 \\
\hline $\mathrm{CD}(\mathrm{P}=0.05)$ & 100 & 121 & 144 & 161 \\
\hline \multicolumn{5}{|l|}{ Interaction (D X S) } \\
\hline S. Em \pm & 59 & 71 & 84 & 95 \\
\hline $\mathrm{CD}(\mathrm{P}=0.05)$ & NS & NS & NS & NS \\
\hline
\end{tabular}

The decline in seed yield of soybean with delayed sowing could be attributed to a shorter length of growing season leading to overall reduction in growth; short days associated with low radiation and low temperature contributing to slower growth rates and lower pod set, and a dramatic reduction in the relative duration of key phenophases which mostly resulted from reduced photoperiod (Zhang et al., 2010). The shorting of duration at various growth phases in the late sown crop might be the probable reason of the reduction in haulm yield (Kumar et al., 2008).

Among plant densities crop sown at 3,33,333 plants ha ${ }^{-1}$ with closer spacing of $30 \mathrm{~cm} \mathrm{x} 10$ 
$\mathrm{cm}$ was proved significantly superior to get higher seed and haulm yield over 1, 66,666 plants $\mathrm{ha}^{-1}$ and 1,11,111 plants ha ${ }^{-1}$. The highest seed yield at higher plant density might be due to early canopy closure in the narrow rows that facilitate high TDM production. The increased leaf area development with higher plant density contributed to increased TDM production due to more solar radiation interception that contributed to higher yield production (Ball et al., 2000).

In concluding remarks, based on two years experimental results optimum sowing time and plant density for soybean would be 26 June with plant density of $3,33,333$ plants ha ${ }^{-1}$ at a spacing of $30 \times 10 \mathrm{~cm}$ is proved to be best to obtain higher seed yield in South Telangana Agro climatic zone of Telangana State.

\section{References}

Board, J.E. and Harville, B.G. 1996. Growth dynamics during the vegetative period affects yield of narrow-row, late-planted soybean. Agron. J., 88: 567-572.

Boquet, D.J and Clawson, E.L. 2007. Planting dates for soybean varieties in North Louisiana. Ouisiana Agriculture Magazine, LSUA, center.com

Chen, G.H. and Wiatrak, P. 2010. Soybean development and yield are influenced by planting date and environmental conditions in the southeastern coastal plain, United States. Agron. J., 102: 17311737.

Gomez, K.A. and Gomez, A.A. 1984. Statistics procedures for agricultural research 2 nd Ed. An International Rice Research Institute, John Willey and Sons, New York.
Han, T.F., C.X. Wu, Z. Tong, R.S. Mentreddy, K.H. Tan and Gai, J.Y. 2006. Post flowering photoperiod regulates vegetative growth and reproductive development of soybean. Environmental and Experimental Bot., 55: 120-129.

$\mathrm{Hu}, \mathrm{M}$. and Wiatrak, P. 2012. Effect of planting date on soybean growth, yield, and grain quality: Review. Agron. J., 104: 785-790.

Kumar, A., V. Pandey, Shekh, A.M and Kumar, M. 2008. Growth and Yield Response of Soybean (Glycine max L.) In Relation to Temperature, Photoperiod and Sunshine Duration at Anand, Gujarat, India. American-Eurasian J. Agron., 1(2): 4550.

Kumudini, S.V., P.K. Pallikonda and Steele, C. 2007. Photoperiod and e-genes influence the duration of the reproductive phase in soybean. Crop Sci., 47: 1510-1517.

Rahman, M.M., Hampton, J.G. and Hill, M.J. 2005. Soybean seed yield as affected by time of sowing in a cool temperature environment. Seed Sci. Technol., 7: 1-15.

Wade, F.F. and Johnston, T.H. 1975. Effect of seeding date on growth and performance of rice in Arkansas Agri Exp Sta Univ Arkansas, Report Series 224.

Yari, V., F. Amin, M. Abbas, M. Meysam, N. Rahim, Mahboubeh. $\mathrm{G}$ and Ahmad, L. 2013. Yield and yield Components of Soybean Cultivars as Affected by Planting Date. Bull. Environ. Pharmacol. Life Sci., 2(7): 85- 90.

Zhang, Qiu-ying., Qing-lu Gao, S.J., Herbert, Yan-sheng Li and Hashemi, A.M. 2010. Influence of sowing date on phenological stages, seed growth and marketable yield of four vegetable soybean cultivars in North-eastern USA. African J. Agri. Res., 5(18): 2556-2562.

\section{How to cite this article:}

Mahesh, N., G. Sreenivas, P. Leela Rani, Akhilesh Gupta, P.D. Sreekanth and Surekha, K. 2017. Growth and Yield of Soybean under Varied Environments and Plant Densities in South Telangana Agro Climatic Zone. Int.J.Curr.Microbiol.App.Sci. 6(8): 1839-1844.

doi: https://doi.org/10.20546/ijcmas.2017.608.216 